\title{
Use of the Learning Cycle model in Teaching some field and track competitions And its effect on the achievement Level And retention of learning effect of the preparatory phase students
}

\section{Dr/ Mohamed Abdelkader Al-Sharkawy}

\section{Abstract}

This research aims at building educational program using the learning cycle model strategy and identification of its effect on the skill and cognitive acheivment standard and retention of the effect of learning in the physical education lesson of the preparatory stage students. The researcher used the experimental methodology by design of two groups; the first is experimental group (used the learning cycle model) $(n=25)$ and second control group (and used the method of presentation and explanation) $(n=25)$. They were chosen by the random purposeful method of the students of Al Kafrawy Experimental School in the New Damietta Educational Department for the academic year 2013/2014 AD. The researcher applied the basic experiment of the research. After collection of data and statistic manipulation, the research concluded that the teaching program using the learning cycle model was more effective on the learning of some field and track competitions under research than the conventional method (presentation and explanation) and the cognitive achievement standard, which signifies its effectiveness and positive effect.

\section{Key words:}

( learning cycle model - retention of learning - achievement level )

\section{Introduction and problem of the research:}

Developed countries that reflect the cultural paid attention to physical development of society, and its education because of its constructive goals that help comprehensively prepare the students in all personal sides whether mental, physical, psychological or social. Physical education has become one of the general indicators development has become a necessity of life and important social duty that we shall foster its achievement.

Mohamed

Hassan Allawy (2002 AD) notes that learning is a process of change or modification of behavior of 
the living organism itself by type of activity. It is conditioned that this change or modification was done as a result of maturity or temporary cases such as tiredness, anesthesia or the like (25:26)

Learning has become one of the key issues to which countries pay much attention. It is objective scale of the progress of countries. This progress is measured by the knowledge means, methods and theories of modern training and development of these countries (13:26)

The learning cycle is one of the teaching methods that focus on the practical side through which students learn, and depends on the equal roles of both the student and the teacher to make the student pivot of the ed ucaitonal process by making him discover and adopt the concept then apply this concept to a new idea. This method was originally designed for teaching of the different curricula and courses as it is characterized by considering the mental capacities of learner and fostering the development of thinking skills of learner well. (11:213)
Effat Al-Tanawy (2003) notes that effective learning is the learning that makes student search and discover knowledge by himself, not to provide knowledge ready for him. The student can promote his mental perceptions and build his knowledge. This was confirmed by the constructivist theory that student builds his knowledge by himself under supervision and direction by teacher. Many teaching methods that derived their theoretical framework from Piaget's theory of mental development were created. There are many teaching methods on which it relies, such as the learning cycle model. (14:21)

Long time ago, children were concerned with competition with each other and placed themselves in comparison with others. Therefore, athletics, because of their variaous competitions, create excellent forum for this type of noble competition, so athletics will remain suitable opportunity for this exchange. Consequently, sports lovers shall pay attention to creation of competitions fit for children. (5:5) 
The learning cycle model in the United States. It is one of the teaching methods that derive its originals and theoretical framework from Piaget's theory of cognitive development. Its design is credited to Atckin and Karplus. Karplus and others introduced some modifications to it in (1974 AD) as it was used to improve the teaching of sicence in the American primary schools. Other programs were based on the learning cycle such as the project of Nebraska University. Academic units were formed in different curricula to contain group of learning cycles. Each cycle comprises lesson of three phases: detection phaseconcept presentation phaseapplication phase $(142: 35)$

\section{Aims of the research:}

The purpose of this research is to build educational program using the learning cycle model, and identifying its effect on the level of cognitive achievement and retention of the effect of learning of some methodological field and track competitions.

\section{Terms of the research:}

\section{Learning cycle:}

Teaching method that depends on the equal roles of the teacher and learner, and proceeds in accordance with three steps of the phase of discovery, phase of concept presentation and phase of concept application (71:11)

\section{Population and Sample of the research:}

The research sample was chosen upon the purposeful method of students of the first preparatory grade in the New Damietta Educational Directorate, Damietta Governorate, who are entered in the Directorate records for the academic year 2013-2014 AD (2665) students. The researcher chose students of the first preparatory grade in Al-Kafrawy Experimental School (160 students) with percentage of $(6.00 \%)$. The researcher chose the research sample in the random purposeful method of the first preparatory grade students in Al-Kafrawy Experimental School for the school year 2013-2014 AD. They were (50) students with percentage of $(31 \%)$ and were divided into two groups, one experimental and the other control. Each group consisted of (25) students and (20) students for pilot studies. 
Data Collection Means

- The researcher collected the information and data related to this research based on the following means and tools:

- Systems and tools used in the research:

- Restameter to measure the body height in centimeter.

- Medical scale for weight measurement in kilogram.

- Computer

- Stopwatch (to measure time)

- Measurement tape (to measure distance)

- Forms and tests:

- Data registration form: Attachment (1)

- Expert questionnaire form on the determination of the key components of physical fitness of field and track competitions suitable to the age group. Attachment (2)

- Questionnaire form of the experts opinion on the items of cognitive achievement test of some field and track competitions: attachment (5)

- Questionnaire form of the experts opinion on the structure of cognitive achievement test: attachment (6)

- Form of evaluation of skill performance of methodological field and track competitions: attachment (8)

\section{- Physical}

Attachment(3)

tests:
- The physical components of field and track competition sutiable to the age group udner research and the best physical tests they measure were defined by the experts opinion questionnaire form (attachment 2) that was presented to the experts. Based on this form, the physical tests that measure the physical variables of the sample of the research were chosen, attach. (3)

\section{- Academic achievement test designed by the researcher:}

The researcher designed test to measure the students' achievement of the cognitive side of some field and track competitions under research. The test contained two basic sides: The first side relates to the legal rules related to some competitions, and the second side is related to the skill performance of some field and track competitions under research. Attachment (5)

\section{- Teaching methods:}

The teaching modules for field and track competitions were taught using the learning cycle strategy by raising some questions:

- Evlauation: The researcher followed to 
approaches of evaluation as follows:

1- Progressive evaluation: This included questions that call students for thinking, inference and arouse their attention.

2- Final evaluation: through the pst measurement based on the skill performance evaluation form, attachment (3), and the final measurement of the cognitive test and comparison of it to the scale of the control group to know the effect of the proposed program on the experimental group.

Table (1)

Arithmetic means, standard deviation and T-value between the average pre and post measurements of the experimental group in the phases of performance and level of skill performance of the 30-m running competition under research $\mathrm{N}=25$

\begin{tabular}{|c|c|c|c|c|c|c|c|c|}
\hline \multirow{2}{*}{ No } & \multirow{2}{*}{ Phase } & \multirow{2}{*}{$\begin{array}{l}\text { Measurement } \\
\text { unit }\end{array}$} & \multicolumn{2}{|c|}{ pre tests } & \multicolumn{2}{|c|}{ post tests } & \multirow{2}{*}{$\begin{array}{c}\text { The } \\
\text { Difference }\end{array}$} & \multirow{2}{*}{$\begin{array}{l}\text { Value } \\
(\mathrm{T})\end{array}$} \\
\hline & & & $\overline{\mathrm{x}}$ & $\sigma$ & $\overline{\mathrm{x}}$ & $\sigma$ & & \\
\hline 1 & $\begin{array}{c}\text { Low } \\
\text { starting }\end{array}$ & Degree & 2.92 & 0.81 & 5.92 & 0.81 & $3.00-$ & 12.60 \\
\hline 2 & Starting & Degree & 0.48 & 0.51 & 3.40 & 0.87 & $2.92-$ & 13.09 \\
\hline 3 & $\begin{array}{l}\text { Running the } \\
\text { distance }\end{array}$ & Degree & 1.32 & 0.80 & 3.44 & 0.82 & $2.12-$ & 8.82 \\
\hline 4 & $\begin{array}{l}\text { Finishingthe } \\
\text { competition }\end{array}$ & Degree & 0.96 & 0.84 & 3.16 & 0.69 & $2.20-$ & 10.18 \\
\hline 5 & $\begin{array}{c}\text { Skill } \\
\text { performance } \\
\text { level } \\
\end{array}$ & Degree & 5.68 & 1.52 & 15.92 & 1.78 & $10.24-$ & 19.92 \\
\hline
\end{tabular}

T-value of table at $0.05=0.06$

The above table (1) indicates that there are statistically significant differences at 0.05 between the average pre and post measurements in the phases of

performance and skill performance level of the running competition of 30 meter under research for the favor of thepost measurements of the experimental group. 
Table (2)

Arithmetic means, standard deviation and T-Value between the average pre and post measurements of the control group in the phasesof performance and skill performance of the long jumping competition under research $\mathrm{N}=25$

\begin{tabular}{|c|c|c|c|c|c|c|c|c|}
\hline \multirow{2}{*}{ No } & \multirow{2}{*}{ Phase } & \multirow{2}{*}{$\begin{array}{c}\text { Measurement } \\
\text { unit }\end{array}$} & \multicolumn{2}{|c|}{ pre tests } & \multicolumn{2}{|c|}{ post tests } & \multirow{2}{*}{$\begin{array}{c}\text { The } \\
\text { Difference }\end{array}$} & \multirow{2}{*}{$\begin{array}{c}\text { Value } \\
\text { (T) }\end{array}$} \\
\hline & & & $\overline{\mathrm{X}}$ & $\sigma$ & $\overline{\mathrm{x}}$ & $\sigma$ & & \\
\hline 1 & Approach & Degree & 0.96 & 0.79 & 3.28 & 0.84 & $2.32-$ & 9.05 \\
\hline 2 & Rising & Degree & 1.68 & 0.99 & 4.12 & 0.93 & $2.44-$ & 10.23 \\
\hline 3 & Flying & Degree & 1.08 & 0.81 & 3.96 & 1.06 & $2.88-$ & 10.12 \\
\hline 4 & Fall & Degree & 0.92 & 0.81 & 3.28 & 0.79 & $2.36-$ & 10.26 \\
\hline 5 & $\begin{array}{l}\text { Skill } \\
\text { performance } \\
\text { level }\end{array}$ & Degree & 4.64 & 1.80 & 14.64 & 1.68 & $10.00-$ & 19.61 \\
\hline
\end{tabular}

Table T-Value at $0.05=2.06$

Table (2) indicates that there are statistically significant differences at 0.05 for the favor of pre and post measurements in the phases of performance and skill

performance level of the long jumping competition by squat method under research for the favor of post measurements of the control group.

Table (3)

Arithmetic means, standard deviation and T-Value between the average pre and post measurements of the experiemntal group in the level of cognitive achievement under research $\mathrm{N}=25$

\begin{tabular}{|c|c|c|c|c|c|c|c|c|}
\hline \multirow{2}{*}{ No } & \multirow[t]{2}{*}{ Item } & \multirow{2}{*}{$\begin{array}{c}\text { Measurement } \\
\text { unit }\end{array}$} & \multicolumn{2}{|c|}{ pre tests } & \multicolumn{2}{|c|}{ post tsts } & \multirow{2}{*}{$\begin{array}{c}\text { The } \\
\text { Difference }\end{array}$} & \multirow{2}{*}{$\begin{array}{c}\text { Value } \\
(\mathbf{T})\end{array}$} \\
\hline & & & $\overline{\overline{\mathbf{x}}}$ & $\sigma$ & $\overline{\mathbf{x}}$ & $\sigma$ & & \\
\hline 1 & $\begin{array}{c}\text { Rules and } \\
\text { laws }\end{array}$ & Degree & 2.40 & 0.50 & 5.36 & 0.49 & $1.68-$ & 8.50 \\
\hline 2 & Skill content & Degree & 4.64 & 0.57 & 11.48 & 0.77 & $1.40-$ & 6.48 \\
\hline 3 & $\begin{array}{c}\text { Cognitive } \\
\text { acheivmenet }\end{array}$ & Degree & 7.04 & 0.79 & 16.84 & 0.94 & $1.76-$ & 8.07 \\
\hline
\end{tabular}

T value of table at $0.05=2.06$

Table (3) indicates that there are statistically significant differences at 0.05 between the average pre and post measurements of the control

group in the level of cognitive achievement under research for the favor of the post measurement of the experimental group. 
Table (4)

Arithmetic means, standard deviation and T-Value between the average pre and post measurements of the control group in the phases of performance and skill performance level of the 30-meter running competition under research $\mathrm{N}=25$

\begin{tabular}{|c|c|c|c|c|c|c|c|c|}
\hline \multirow{2}{*}{ No } & \multirow{2}{*}{ Phase } & \multirow{2}{*}{$\begin{array}{l}\text { Measurement } \\
\text { unit }\end{array}$} & \multicolumn{2}{|c|}{ pre tests } & \multicolumn{2}{|c|}{ post tests } & \multirow{2}{*}{$\begin{array}{l}\text { The } \\
\text { Difference }\end{array}$} & \multirow{2}{*}{$\begin{array}{l}\text { Value } \\
\text { (T) }\end{array}$} \\
\hline & & & $\overline{\mathbf{x}}$ & $\sigma$ & $\overline{\mathbf{x}}$ & $\sigma$ & & \\
\hline 1 & Low starting & Degree & 2.68 & 0.75 & 3.48 & 1.08 & $0.80-$ & $3.70-$ \\
\hline 2 & Starting & Degree & 0.52 & 0.51 & 2.56 & 0.71 & $2.04-$ & $12.92-$ \\
\hline 3 & $\begin{array}{l}\text { Running the } \\
\text { distance }\end{array}$ & Degree & 1.04 & 0.84 & 2.68 & 0.69 & $1.64-$ & 7.13- \\
\hline 4 & $\begin{array}{l}\text { Finishingthe } \\
\text { competition }\end{array}$ & Degree & 0.92 & 0.70 & 2.52 & 0.65 & $1.60-$ & 7.69- \\
\hline 5 & $\begin{array}{c}\text { Skill performance } \\
\text { level }\end{array}$ & Degree & 5.16 & 1.43 & 11.24 & 1.64 & $6.08-$ & 13.72- \\
\hline
\end{tabular}

T value of table at $0.05=2.06$

Table (4) indicates that there are statistically significant differences at 0.05 between the average pre and post measurements in the phases of performance and

Table (5)

Arithmetic means, standard deviation and T-Value between the average pre and post measurements of the control group in the phases of performance and skill performance level of the long jump competition under research $(\mathrm{N}=25)$

\begin{tabular}{|c|c|c|c|c|c|c|c|c|}
\hline \multirow{2}{*}{ No } & \multirow[b]{2}{*}{ Phase } & \multirow{2}{*}{$\begin{array}{l}\text { Measurement } \\
\text { unit }\end{array}$} & \multicolumn{2}{|c|}{ pre tests } & \multicolumn{2}{|c|}{ post tests } & \multirow{2}{*}{$\begin{array}{l}\text { The } \\
\text { Difference }\end{array}$} & \multirow{2}{*}{$\begin{array}{l}\text { Value } \\
\text { (T) }\end{array}$} \\
\hline & & & $\overline{\overline{\mathrm{x}}}$ & $\sigma$ & $\overline{\overline{\mathrm{x}}}$ & $\sigma$ & & \\
\hline 1 & Approach & Degree & 0.80 & 0.76 & 2.36 & 0.64 & $1.56-$ & 8.51 \\
\hline 2 & Rising & Degree & 1.32 & 0.80 & 3.12 & 0.88 & $1.80-$ & 6.65 \\
\hline 3 & Flying & Degree & 1.32 & 0.80 & 3.00 & 0.87 & $1.68-$ & 8.50 \\
\hline 4 & Fall & Degree & 0.96 & 0.79 & 2.52 & 0.59 & $1.56-$ & 8.12 \\
\hline 5 & $\begin{array}{l}\text { Skill performance } \\
\text { level }\end{array}$ & Degree & 4.40 & 1.94 & 11.00 & 1.47 & $6.60-$ & 15.28 \\
\hline
\end{tabular}

$\mathrm{T}$ value of table at $0.05=2.06$ 
Table (5) indicates that there are statistically significant differences at 0.05 between the average pre and post measurementsin the phases of performance and skill perforfmance level of the long jumping competition by squat method under research for the favor of the post measurements of the control group.

Table (6)

Arithmetic means, standard deviation and T-Value between the average pre and post measurements of the control group in the level of cognitive achievement under research $N=25$

\begin{tabular}{l|l|l|r|l|l||l|l|l}
\hline \hline \multirow{2}{*}{ No } & \multirow{2}{*}{ Item } & \multirow{2}{*}{$\begin{array}{l}\text { Measurement } \\
\text { unit }\end{array}$} & \multicolumn{2}{|l|}{ pre tests } & \multicolumn{2}{l|}{ post tests } & The & $\begin{array}{l}\text { Value } \\
\text { Difference } \\
(\mathrm{T})\end{array}$ \\
\hline \hline 1 & & & $\overline{\mathrm{x}}$ & $\sigma$ & $\overline{\mathrm{x}}$ & $\sigma$ & & \\
\hline 2 & $\begin{array}{l}\text { Rules and } \\
\text { laws }\end{array}$ & Degree & 2.36 & 0.49 & 3.64 & 0.49 & $1.28-$ & 8.08 \\
\hline 3 & $\begin{array}{l}\text { Cognill content } \\
\text { acheivmenet }\end{array}$ & Degree & 4.48 & 0.51 & 7.60 & 0.50 & $3.12-$ & 23.43 \\
\hline \hline
\end{tabular}

$\mathrm{T}$ value of table at $0.05=2.06$

Table (6) indicates that there are statistically significant differences at 0.05 between the average pre and post measurementsof the control

Table (7)

group in the level of cognitive achievement under research for the favor of the post measurement of the control group.

Arithmetic means, standard deviation and T-Value between the average pre and post measurements of the control group and experimental group in the phases of performance and skill performance level of the 30-meter running competition under research $\mathrm{N}=\mathbf{5 0}$

\begin{tabular}{|c|c|c|c|c|c|c|c|c|}
\hline \multirow{2}{*}{ No } & \multirow{2}{*}{ Phase } & \multirow{2}{*}{$\begin{array}{l}\text { Measurement } \\
\text { unit }\end{array}$} & \multicolumn{2}{|c|}{$\begin{array}{l}\text { Experimental } \\
\text { group }\end{array}$} & \multicolumn{2}{|c|}{$\begin{array}{l}\text { control } \\
\text { group }\end{array}$} & \multirow{2}{*}{$\begin{array}{c}\text { The } \\
\text { Difference }\end{array}$} & \multirow[t]{2}{*}{$\begin{array}{l}\text { Value } \\
\text { (T) }\end{array}$} \\
\hline & & & $\overline{\mathrm{x}}$ & $\sigma$ & $\overline{\mathrm{x}}$ & $\sigma$ & & \\
\hline 1 & Low starting & Degree & 5.92 & 0.81 & 3.48 & 1.08 & 2.44 & 9.00 \\
\hline 2 & Starting & Degree & 3.40 & 0.87 & 2.56 & 0.71 & 0.84 & 3.75 \\
\hline 3 & $\begin{array}{l}\text { Running the } \\
\text { distance }\end{array}$ & Degree & 3.44 & 0.82 & 2.68 & 0.69 & 0.76 & 3.54 \\
\hline 4 & $\begin{array}{l}\text { Finishingthe } \\
\text { competition }\end{array}$ & Degree & 3.16 & 0.69 & 2.52 & 0.65 & 0.64 & 3.37 \\
\hline 5 & $\begin{array}{l}\text { Skill } \\
\text { level }\end{array}$ & Degree & 15.92 & 1.78 & 11.24 & 1.64 & 4.68 & 9.67 \\
\hline
\end{tabular}

$\mathrm{T}$ value of table at $0.05=2.06$ Assiut Journal For Sport Science Arts 
Table (7) indicates that there are statistically significant differences at 0.05 between the average pre and post measurementsof the experimental group and the control group in the phases of performance and skill performance standard of the 30-meter running competition for the favor of the post measurements of the experimental group.

Table (8)

Arithmetic means, standard deviation and T-Value between the pre and post measurements of the control group and experimental group in the phases of performance and skill performance level of the long jump competition under research $\mathrm{N}=\mathbf{5 0}$

\begin{tabular}{|c|c|c|c|c|c|c|c|c|}
\hline \multirow[b]{2}{*}{ No } & \multirow[b]{2}{*}{ Phase } & \multirow[b]{2}{*}{$\begin{array}{l}\text { Measurement } \\
\text { unit }\end{array}$} & \multicolumn{2}{|c|}{ pre tests } & \multicolumn{2}{|c|}{ Post tests } & \multirow[b]{2}{*}{$\begin{array}{l}\text { The } \\
\text { Difference }\end{array}$} & \multirow[b]{2}{*}{$\begin{array}{l}\text { Value } \\
\text { (T) }\end{array}$} \\
\hline & & & $\overline{\mathrm{x}}$ & $\sigma$ & $\overline{\mathrm{x}}$ & $\sigma$ & & \\
\hline 1 & Approach & Degree & 3.28 & 0.84 & 2.36 & 0.64 & 0.92 & 4.35 \\
\hline 2 & Rising & Degree & 4.12 & 0.93 & 3.12 & 0.88 & 1.00 & 3.91 \\
\hline 3 & Flying & Degree & 3.96 & 1.06 & 3.00 & 0.87 & 0.96 & 3.51 \\
\hline 4 & Fall & Degree & 3.28 & 0.79 & 2.52 & 0.59 & 0.76 & 3.86 \\
\hline 5 & $\begin{array}{l}\begin{array}{l}\text { Skill } \\
\text { performance } \\
\text { lever }\end{array} \\
\end{array}$ & Degree & 14.64 & 1.68 & 11.00 & 1.47 & 3.64 & 8.15 \\
\hline
\end{tabular}

$\mathrm{T}$ value of table at $0.05=2.01$

Table (8) indicates that there are statistically significant differences at 0.05 between the average pre and post measurementsof the experimental group and the control group in the phases of

performance and skill performance standard of the long jumping competition for the favor of the post measurements of the experimental group. 
Table (9)

Arithmetic means, standard deviation and $T$ value between the post measruements of the experimental group and control group in the level of cognitive achievement under research $(\mathrm{N}=50)$

\begin{tabular}{|c|c|c|c|c|c|c|c|c|}
\hline \multirow{2}{*}{ No } & \multirow{2}{*}{ Item } & \multirow{2}{*}{$\begin{array}{l}\text { Measurement } \\
\text { unit }\end{array}$} & \multicolumn{2}{|c|}{$\begin{array}{l}\text { Experimental } \\
\text { group }\end{array}$} & \multicolumn{2}{|c|}{$\begin{array}{l}\text { Control } \\
\text { group }\end{array}$} & \multirow{2}{*}{$\begin{array}{l}\text { The } \\
\text { Difference }\end{array}$} & \multirow{2}{*}{$\begin{array}{l}\text { Value } \\
(\mathbf{T})\end{array}$} \\
\hline & & & $\overline{\mathbf{x}}$ & $\sigma$ & $\overline{\mathbf{x}}$ & $\sigma$ & & \\
\hline 1 & $\begin{array}{l}\text { Rules and } \\
\text { laws }\end{array}$ & Degree & 5.36 & 0.49 & 3.64 & 0.49 & 1.72 & 12.41 \\
\hline 2 & $\begin{array}{l}\text { Skill } \\
\text { content }\end{array}$ & Degree & 11.48 & 0.77 & 7.60 & 0.50 & 3.88 & 21.13 \\
\hline 3 & $\begin{array}{l}\text { Cognitive } \\
\text { acheivmenet }\end{array}$ & Degree & 16.84 & 0.94 & 11.24 & 0.66 & 5.60 & 24.28 \\
\hline
\end{tabular}

$T$ value of table at $0.05=2.01$

Table (9) indicates that there are statistically significant differences at 0.05 between the average pre and post measurementsof the experimental group and the control group in the level of cognitive achievement under research for the favor of the post measruements of the xperimental group.

\section{Discussion of Results:}

Tables

(1) and indicate that there are statistically significant differences between the pre measurements and post measurements of the experimental group for the favor of the post measurement in the performance standard of some field and track competitions and cognitive achievement under research

(running 30 meter, long jumping by squat method).

The experimental group was taught through the learning cycle strategy. Therefore, the researcher finds that those differences are attributed to the effect of the proposed learning program using the learning cycle strategy in teaching the phases of technical performance of some field and track competitions under research.

The researcher concluded that the use of learning cycle as a teaching program for teaching the phases of technical performance of the skills under research is effective and has positive effect on the desired learning process because it helps the teacher to define and 
classify the educational goals in easily achievable behavioral objectives. It indicates how the teaching modules are built and planned, and helps the teacher to complete the evaluation of students by choosing the suitable methods. Due to the positive results and data concluded before for the favor of the pre measurement, this indicates progress of the skill performance after application of the proposed teaching modules of the experimental group.

This agrees with the study of Abdulhafez Youssef Al-Seddik (2001 AD) (19); Ebtessam Mohamed Fares (2003 AD) (1); Mai Omar Abdulaziz (2003 AD) (29); Amany Helmy Abdulhamid (2006 AD) (7); Mohamed Ahmed Ali (2011 AD) (24) whose key studies results noted the effectiveness of using the learning cycle on the teaching of skills under research.

Table (4) indicates statistically significant differences between the average pre measurements and post measurements of the control group for the favor of the post measurement in the level of cognitive achievement of the systematic ield and track competitions under research (30- meter running, long jumping by squat method). The calculated $(\mathrm{T})$ value was higher than the table $(\mathrm{T})$ value at (0.05).

The researchers attribute the use of learning cycle strategy of teaching the experimental group positively affected the level of cognitive achievmenet of the experimental group students. Use of the teaching cycle method helps increase the students' motivation to learning, which led to increase of their learning of the facts and concepts related to the module, and their readiness to apply them in their different life situations. In addition, diversity of the activities used in this method led to confrontation of the individual differences between the students, which increased their achievement.

This agrees with the study of Ahmed Ibrahim AlGohary (1997 AD) (2); Yossry Taha Mohamed (2001 AD) (31); Heba Abdulmohsen Ahmed (2003 AD) (30); Badr Mubarak Tarkham (2011 AD) (9) whose studies results noted that the learning cycle strategy 
has good effect on the teaching of educational subjects under research. From the foregoing, the validity of the first hypothesis is achieved. This hypothesis states that:

"There are statistically significant differences between the average pre and post measurements of the experimental group for the favor of the post measurements in the skill performance standard and the cognitive achievement and retention of the effect of learning of some field and track competitions of the first preparatory grade students."

$$
\text { Tables (4) and }
$$

indicates statistically significant differences between the pre and post measurements of the control group for the favor of the post measurement in the performance standard of the field and track competitions under research (30-meter running, long jumping by squat method).

Whereas the control group was taught using the conventional method that was applied (explanation and performance of good model) in teaching the skills under research, the researcher suggests that the progress made by the applied method lies in the feasibility of this method that can't be ignored as it depends on the explanation and performance of good model of the related skill. Improvement of the control group performance is attributed to the students' accustomization to this method applied in teaching through their different phases of education.

This agrees with the study of "Doaa Mohie El Din Abu Hend" (2005 AD) (15); Eman Sayed Ahmed (2006 AD) (7); Mohamed Salah Ahmed (2007 AD) (28); Ahmed Mohamed Mohamed (2012 AD) (4). Their results noted that the conventional method achieved progress of the control group in the skill performance standard under research.

Table (6) indicates that there are satistically significant differences between the pre and post measurements of the control group for the favor of the post measurement in the cognitive achievement standard of the systematic field and track competitions under research (30-meter running, long jumping by squat method). The calculated (T) 
value was higher than the $(\mathrm{T})$ value at $(0.05)$.

This agrees with the study of "Doaa Mohie El Din Abu Hend" (2000 AD) (15); Mohamed Salah Ahmed Faleh (2007) (28); Mohamed Mahmoud Moussa (2009 AD) (27); and Taghrid Ahmed Elsayed (2012 AD) (10). The results indicated that the conventional methodi that was applied (explanation and performance of good model) that achieved progress for the control group in the cognitive achievement under their research.

According to the foregoing, the validity of the second hypothesis is confirmed. This hypothesis states that:

"There are statistically significant differences between the average pre and post measurements of the control group for the favor of the post measurements in the skill performance standard and the cognitive achievement and retention of the effect of learning of some field and track competitions of the first preparatory grade students."

Tables (7) and indicate that there are satistically significant differences between the post measurements of the control group and experimental group for the favor of the post measurement in the experimental achievement standard of the systematic field and track competitions under research (30-meter running, long jumping by squat method).

The researcher attributes this to the fact that the learning cycle strategy focues on that learner is the pivot of teaching process as he identifies and discusses the problem and studies its proper practical application. The learning cycle strategy depends on partitioning of skill into parts in accordance with three phases in the form of dynamic duty. In each phase the study, through the exploration of his capacities, potentials and experimentations, and during this period the teacher provides the student with set of follow up questions of each phase of the learning cycle strategy phases in the form of dynamic stimulators so that the student reaches the right response, through the observation whether individual or group through the teacher's supervision of students during 
performance. This is done through discussion and dialogue between teacher and students.

This agrees with the study of Hassan Mohamed Huwail (2001 AD) (13); Zakaria Gaber Hennawy (2004 AD) (17); Mohamed Ahmed Ali (2011 AD) (24); Mai Omar Abdulaziz (2003 AD) (29) whose results indicated that the learning cycle strategy has significant effect on the development of skills under their research.

Table (9) indicates that there are satistically significant differences between the pre measurements of the control group and experimental group for the favor of the experimental group in the cognitive achievement standard of the systematic field and track competitions under research (30-meter running, long jumping by squat method). The calculated (T) value was higher than the $(\mathrm{T})$ value at $(0.05)$.

The researcher attributes the superiority of the experimental group over the control group the results of improvement of cognitive acheivment of the experimental group to the use of the learning cycle model with the experimental group as the learning cycle makes learner the pivot of learning process. His role is active through participation in the activities. The cycle allows the student to experiment, discover and impose hypothesis till he reaches the right answer. In addition, the learner, through the use of learning cycle strategy, builds his knowledge by himself through direct exposure to the learning environment. Good knowledge is combined with the learner's knowledge and this results in combination and development of his cognitive structure.

This agrees with the study of Yossry Mohaemd Taha (2001 AD) (31); Heba Abdulmohsen Ahmed (2003 AD) (30); Amany Helmy Abdulhamid (2001 AD) (6); Badr Mubarak Tarkham (2011 AD) (9).

The foregoing indicates that the third hypothesis is satisfied. This hypothesis states that:

"There are statistically significant differences between the average pre and post measurements of the experimental group and control group for the favor of the post epxeirmental group in the skill 
performance standard and the cognitive achievement and retention of the effect of learning of some field and track competitions of the first preparatory grade students."

\section{Conclusions:}

-The learning cycle strategy positively contributed to the learning of some field and track competitions of the primary stage students under research, and the cognitive achievement level of the members of experimental group improved.

- The learning program using the learning cycle strategy was more effective on the learning of some field and track competitions under research than the conventional method (presentation and explanation), which indicates its effectiveness and effect.

-The learning program using the learning cycle was the most effective on the level of cognitive achievement of information related to some field and track competitions of the first preparatory grade students than the conventional method, which indicates its effectiveness.

\section{References:}

\section{1- Ebtessam Mohamed}

Fares (2003 AD):

"Effectiveness of using the learning cycle on development of problem solving and academic achievement skills of the general secondary in Psychology", unpublished master thesis, Insittute of Educational Studies and Research, Caior University.

2- Ahmed Ibrahim AlGohary (1997 AD): Effectiveness of using the learning cycle and advanced regulator in the improvement of achievement of some scientific concepts and learning and thinking patterns in the first general secondary grade students, unpublished master thesis, Faculty of Education, Tanta University.

3- Ahmed Mohamed Khedr (2004 AD): Effectiveness of using the learning cycle and scientific presetnations in the achievement of some objectives of teaching science in the preparatory stage, Master Thesis, Faculty of Education, Zagazig University. 4- Ahmed Mohamed Mohamed (2012 AD): Use of learning cycle strategy in teaching of some competitions 
and its effect on the achievement level of the primary stage students, Scientific Magazien of Physical and Sports Education Research, Faculty of Physical Education, Benha University.

\section{5- International}

Feaderation of Amateurs Athletics (2006 AD): "Effect of using the learning cycle strategy on the teaching of rhetorical concepts on the immediate and relayed achievement of the general secondary students", Magazine of Reading and Knowledge, Egyptian Society of Learning and Knowledge, Faculty of Education, Ain Shams University, Vol. 64, March. 6- Eman Sayed Ahmed (2006 AD): "Effect of the use of duty analysis approach on the learning of some volleyball skills to the first year students in the Faculty of Physical Education, Assiut University", unpublished master thesis, Faculty of Physical Education, Assiut University.

7- Bastawissy

Ahmed

Bastawissy (1997 AD): Track and field competitions, "Teaching of training tactic", Dar Al-Fekr Al-Araby, Cairo. 8- Badr Mubarak Tarkham Al-Shamrany (2011
AD): "Effectiveness of using the learning cycle model in the teaching of sports on the development of achievement and creative thinking skills in the fifth primary grade students in the Kingdom of Saudi Arabia", unpublished master thesis, Institute of Educational Studies, Cairo University.

9- Taghreed Ahmed El Sayed (2012): Effect of using the learning cycle approach on the teaching of some basic attack skills in basketball on the skill achievement and retention of the effect of learning, Magazine of Sports Science and Applications of Physical Education, Faculty of Physical Education, Menya Univeristy.

10- Hassan

Hussein

Zeitoun (1992): Department of learning new method of teaching science, Magazien of Modern Science, May, No. 2.

\section{1- Hassan}

Hussein

Zeitoun (2003 AD): Teaching Strategies, Modern vision of the methods of learning and teaching, No. 1, Alam AlKutub, Cairo.

\section{2- Hassan Mohamed}

Huwail (2001 AD): "Effect of the use of learning cycle for teaching the electrical concepts on the achievement and 
development of some scientific thinking skills in the first secondary grade students, Master Thesis, Faculty of Education, Assiut University."

13- Hamdy Mohamed AlBetar (2006 AD): "Effeciveness of using the learning cycle model in the development of academic acheivmeent and attitude to the subject of hydraulics in the third secondary grade students", First Scientific Conference, Learning and Development in New Societies, 5-6 March, Faculty of Education in the New Valley, Assiut University.

14- Doaa Mohie El Din Abu Hend (2000 AD): "Effect of the Use of some teaching approaches on the learning of disc throwing competition", $\mathrm{PhD}$ thesis, Tanta University.

\section{5- Zaki Mohamed}

Darweesh, Adel Mahmoud Abdulhafez (1997 AD): Encyclopedia of Athletics", Art of running and sequences, Dar Al-Maaref, Alexandria.

16- Zakaria Gaber AlHennawy (2004 AD): "Effect of the learning cycle model on the teaching of engineering for development of achievement and createive thinking in the preparatory grade students, master thesis, Faculty of Education, Assiut University.

17- Saad El Din Abu Fotouh El Sharnouby (1998 AD): Field and track competitions (track, long distances, marathon, mass pushing, shot put throwing, high jumping), Al-Eshaa Library, Alexandria.

18- Abdulhafez Youssef Al-Seddik (2001 AD): "Use of learning cycle strategy in the teaching of science and its effect on the cognitive achievement and hand skills of the third preparatory grade students", master thesis, Faculty of Education, Souhag.

19- Essam EI Din Metwally Abdullah (2007 AD): Modern approaches of study of physical education curricula, Dar Al Wafaa for Printing and Publishing, Alexandria.

20- Effat Mustafa AlTanawy (2002 AD): Teaching and learning methods and their applications in the educational research, Egyptian Anglo Bookshop.

21- Farag Abdulhamid Tawfiq (2000 AD): Teaching of athletic competitions, AlKetab Publishing Center, Cairo.

22- Magdy Aziz Ibrahim (2004 AD): "Learning 
Strategies and Teaching Styles", Egyptian Anglo Bookshop, Cairo.

\section{3- Mohamed Ahmed Ali} Al-Azraq (2011 AD): "Use of learning cycle strategy in teaching of gramm for the fifth primary grade students and its effect on the cognitive achievement and their written expression and social skills", master thesis, Faculty of Education, Souhag University.

\section{4- Mohamed Hassan}

Alawy (2002 AD): "Training Psychology and Sports Competition", Dar Al Fekr Al Araby, Cairo.

\section{5- Mohamed}

Saad

Zaghloul, Mustafa Al-Sayeh Mohamed (2004 AD): "Technology of preparation and qualification of the physical education teacher", $2^{\text {nd }}$ edition, Dar Al Wafa Printing and Publishing, Alexandria.

\section{6- Mohamed Mahmoud} Moussa (2009 AD): "Effect of the use of learning strategy on the development of rhetorical concepts of the students of Education Department, Major of Arabic", Al-Hesn University, United Arab Emirates, Magazine of Reading and Knowledge, Faculty of Education, Ain Shams
University, $95^{\text {th }}$ edition, Vol. 2, Betemper.

\section{7- Mohamed}

Salah Ahmed Faleh (2007 AD): Reference of academic module for teaching the systematic field and track competitions and its effect on the skill performance of the second stage of elementary education, master thesis, Faculty of Physical Education, Assiut University.

\section{8- Mai Omar Abdulaziz} Al-Sabil (2003 AD): "Effect of the use of learning cycle and answer model on the acquisition of scientific concepts and observation, classification and communication skills by the third primary grade students", unpublished master thesis, Faculty of Women, Faculty of Education, Riyadh.

\section{9- Heba Abdulmohsen}

Ahmed (2003 AD): "Use of the learning cycle in teaching of domestic economy and its effect on the cognitive achievement and hand skills in the first preparatory grade students, master thesis, Faculty of Education, Souhag."

30- Youssry

Taha Mohamed (2001 AD): "Effectiveness of use of the modified learning cycle on 
acheivment and development of scientific thinking skills in physics of the First Secondary Grade Students of different mental capacity", Magazine of Pscyhological and Educational Research, $2^{\text {nd }}$ edition, Faculty of Education, Menoufiya Univeristy.

32 - ceylan , evan , geban , omer (2009) : facilitating conceptud change in understanding state of matter and solubility concepts by using 5e learning cycle model , hacettepe journal of education , eric ed (849328).

33 - duran , Emilio , duran, lean ,haney , scheuermann , changpakron, sasithorn (2007) :investigation of thai teachers use of questions to enhance students thinking skills in reding comprehension ed , D. disseratation ,United states - Colorado , Unversity of northern colorada P143, Ed 3271028 .

34- kaynar,devrim ,tekkaya , ceren , cakiroglu , jale(2009) ;effectiveness of $5 \mathrm{E}$ learning cycle instruction on students Achievement in cell concept and scientific Epistemological Beliefs . Hacettepe university journal of Education Eric ,

35- Lawson , a, e ; (2010):

Exploring growth through a learning cycle "The American Biology, teacher, vol , 53, no ,2,1991, p ,107

36- su,c,y chiu , c ,h,wang (2010) ; " the developmet of scormconformant learning cotent based on the learning cycle using participatory design "jounal articles, reports - research , ej 897863 , p p 392 -406 .

37- yilmaz, diba (2011); "the comparative effects of pre diction discussion - based learning cycle , conceptual change text, and traditional instruction on student understanding of genetics interntional, jornal of science education , ( ERIC ) ED917723 